\begin{tabular}{llr} 
KULTURA & POLSKA A KADEMIA NAUK & ISSN 0023-5172 \\
i & KOMITET SOCJOLOGI & $2300-195 \mathrm{x}$ \\
SPOLCZENSTWO & $\begin{array}{l}\text { INSTYTUT STUDIÓW POLITYCZNYCH } \\
\text { 2020, nr 2 ANTROPOLOGIA ZAANGAŻOWANA }\end{array}$ & \\
\hline
\end{tabular}

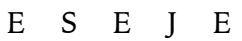
$\begin{array}{llllllllll}\mathrm{R} & \mathrm{E} & \mathrm{C} & \mathrm{E} & \mathrm{N} & \mathrm{Z} & \mathrm{Y} & \mathrm{J} & \mathrm{N} & \mathrm{E}\end{array}$

KRYSTYNA ROMANISZYN

Instytut Socjologii Uniwersytetu Jagiellońskiego

\title{
SPOŁECZEŃSTWO RYNKOWE PO SOCJALIZMIE: KONCEPCJE POLANYIEGO W INTERPRETACJI CHRISA HANNA
}

Książka Repatriating Polanyi: Market Society in the Visegrád States zawiera teksty Chrisa Hanna z lat 1970-2016. Ponadto specjalnie do tego zbioru autor napisał trzy rozdziały: pierwszy będący rodzajem wstępu oraz jedenasty i dwunasty, które pełniące też funkcję podsumowania całości. Rozdziały od drugiego do dziesiątego albo są skonstruowane z poprzednio publikowanych artykułów (często dwóch lub trzech), albo stanowią przedruk jednego artykułu. Hann podkreśla, że wcześniejsze teksty pozostały zasadniczo bez zmian, jeśli nie liczyć niewielkich korekt, które wyraźnie zaznaczył. Taki zamysł, polegający na książka zawiera ogrom wątków, odniesień do literatury $z$ wielu dziedzin wiedzy, wniosków z własnych badań terenowych. Stałe i liczne nawiązania do prac i badań, w tym oczywiście antropologicznych, budują niezwykle szeroką panoramę oglądu świata przede wszystkim w wymiarze społeczno-gospodarczym, lecz nie wyłącznie. Zapowiada to już tytuł książki wskazujący na osobę Karla Polanyiego. Wśród wielu wątków poruszanych przez autora znalazły się te dotyczące etniczności i relacji mniejszość-większość, omawiane na przykładzie odpowiednio Łemków i grekokatolików w Polsce, a także nacjonalizm, transformacja socjalizmu i postsocjalizm, kwestia wsi i własności w erze neoliberalizmu, społeczeństwo rynkowe w państwach Porozumie-

Adres do korespondencji: krystyna.romaniszyn@uj.edu.pl; ORCID: 0000-0002-5800$-3007$ 
nia Wyszehradzkiego oraz projekt zatytułowany „Budowanie społecznej Eurazji”, będący jednocześnie przedmiotem ostatniego, dwunastego rozdziału. Eseistyczna forma narracji, a także jej meandry niejednokrotnie zaciemniają wywody. Nicią wiążącą są propozycje teoretyczne Karla Polanyiego, tytułowego bohatera książki. Hann konstatuje, że jej wiodącym wątkiem jest interpretacja społeczeństwa rynkowego po socjalizmie w nawiązaniu do myśli Polanyiego, zakotwiczona w antropologii gospodarczej pojmowanej nie jako wąska antropologiczna poddyscyplina, lecz jako perspektywa całościowego, materialistycznego oglądu gospodarki ludzkiej. Notabene pomysł odwołania się w namyśle nad socjalizmem do dorobku antropologii społecznej towarzyszy autorowi od dawna (Hann 1993).

Założony cel Repatriating Polanyi zawiera się w dwóch zasadniczych pytaniach, pierwsze brzmi: jakie światło na powstanie i upadek socjalizmu i podobnych epokowych wydarzeń w dziejach może rzucić antropologia społeczno-kulturowa? Jak stwierdza Chris Hann, równie ważne jak uznanie jedności, jak pisze, marksistowsko-leninowsko-maoistycznego socjalizmu jako cywilizacji (Marxist-Leninist-Maoist socialism as a civilization) jest dostrzeżenie odmienności socjalistycznych doświadczeń, które podejmie się zgłębić na przykładzie Węgier i Polski. Na marginesie należy odnotować potrzebę wyjaśnienia przez autora zasadności posługiwania się powyższym konstruktem, a także użytych w nim terminów „cywilizacja” i „socjalizm”, gdy zarządzający ową „cywilizacją” sami posługiwali się terminem „komunizm”. Drugie z wyjściowych pytań brzmi: jaki wkład w rozwój teorii nauk humanistycznych i społecznych, w szczególności antropologii społeczno-kulturowej, mogą wnieść badania socjalizmu i postsocjalizmu? Jak autor od razu dodaje, sercem marksistowsko-leninowsko-maoistycznego socjalizmu w Eurazji są tereny będące przedmiotem specjalizacji niewielu zachodnich antropologów społeczno-kulturowych. Można więc domniemywać, że podjęta przez autora praca wypełnia istniejącą lukę.

Tytułowa postać książki - Karl Polanyi - i jego oryginalna twórczość naukowa, która wywarła duży wpływ także na antropologię, przede wszystkim na wzmiankowaną już antropologię gospodarczą, zasługuje na szczególną uwagę. Karl Polanyi nie był wprawdzie antropologiem i nie uważano go za takiego, jednak jego prace nie tylko dotyczyły problemów z zakresu nauk ekonomicznych, lecz także obejmowały wątki historyczne i antropologiczne. Urodzony w Wiedniu, wychowany w Budapeszcie, gdzie też studiował, po pierwszej wojnie światowej mieszkał w Austrii, potem także w Anglii i Stanach Zjednoczonych, gdzie pracował do końca życia (w 1964 r.), był Karl Polanyi uczonym o bardzo rozległych zainteresowaniach, nie stronił też od publicystyki. 
Warte przywołania są główne twierdzenia Polanyiego dotyczące rzeczywistości społeczno-gospodarczej, budują one bowiem kontekst rozważań przedstawionych przez Hanna. Karl Polanyi uważał za Arystotelesem, że człowiek nie jest istotą ekonomiczną, ale społeczną. Przekonanie to miało kapitalne znaczenie dla jego wizji i interpretacji rzeczywistości gospodarczej. Działalność ekonomiczna, jego zdaniem, zakorzeniona jest w rzeczywistości społeczno-kulturowej, a także politycznej, czyli w instytucjach, wartościach, stosunkach społecznych. „W przeciwieństwie do Marksa uważał, że podporząadkowanie działalności gospodarczej celom społecznym nie istnieje tylko w społeczeństwach pierwotnych lub że będzie istniało kiedyś w komunistycznej utopii, ale że jest cechą wszystkich społeczeństw, oprócz społeczeństw zdominowanych przez ideę leseferyzmu" (Morawski 2011, s. 89). Czerpiąc inspiracje $z$ Weberowskiej typologii działań racjonalnych, wyróżnił kilka form organizacji czy integracji gospodarek, które w interpretacjach jego prac nazywane są też formami transakcji czy alokacji dóbr. Są to: wymiana odwzajemniona, redystrybucja, wymiana rynkowa. Należy przy tym bardzo wyraźnie podkreślić, że owe formy integracji mogą ze sobą współistnieć w ramach jednej gospodarki, co jest częste, jeden z nich może też dominować nad pozostałymi, co również miało i ma miejsce. Historycznie $\mathrm{w}$ gospodarkach ludzkich nad wymianą rynkową dominowały wymiana odwzajemniona i redystrybucja jako ważniejszy czynnik integracji gospodarki. Kluczowym elementem omawianej koncepcji jest stwierdzenie, iż warunkiem powstania każdej formy integracji gospodarki jest uprzednie pojawienie się umożliwiających to instytucji i struktur społecznych. Twierdzenie to jest istotne $z$ dwóch powodów. Po pierwsze, pokazuje Karla Polanyiego jako myśliciela, który nie ogranicza swoich zainteresowań do jednej dyscypliny, lecz — jak już zostało powiedziane - czerpie wie$\mathrm{dzę} \mathrm{i} \mathrm{inspiracje} z$ wielu dziedzin nauki. Po drugie, omawiane twierdzenie stanowi narzędzie interpretacji zarówno zaistniałych, jak i projektowanych form integracji gospodarki. Zatem warunkiem wymiany odwzajemnionej jako (podstawowej) formy integracji gospodarki jest istnienie symetrycznie zorganizowanych struktur, na przykład systemu grup krewniaczych, pomiędzy którymi nastepuje przepływ dóbr, i zwykle nie wiąże się on zyskiem. Warunkiem redystrybucji jako formy integracji gospodarki jest istnienie struktury, na przykład władzy państwowej, pełniącej funkcję alokacyjnego centrum dóbr i usług. Wymiana rynkowa jako forma integracji wymaga istnienia instytucji własności prywatnej oraz, rynków na których dochodzi do ustalenia cen towarów, a celem wymiany jest osiąganie zysku.

Ścisły splot aktywności gospodarczej i struktur społecznych Polanyi obrazuje metaforą „zanurzenia” gospodarki w świecie społecznych struktur 
i instytucji. Notabene założenie to pozwala nadać mu miano „szczególnego funkcjonalisty", jak czyni to Chris Hann. Był nim jednak z przypadku, a nie $z$ wyboru. Niezamierzonym skutkiem uznania za pierwszoplanową idei - użytej wszak przez Polanyiego metaforycznie — „zanurzenia” gospodarki w świecie instytucji społecznych było ugruntowanie dychotomicznej wizji gospodarek ludzkich: tych zanurzonych (embedded) w świecie instytucji społecznych i utożsamianych z gospodarkami tradycyjnymi oraz gospodarki rynkowej. W uzasadnieniu swojej teorii gospodarek Polanyi przekonywał o konieczności „uwolnienia się od zakorzenionego $\mathrm{w}$ nas przeświadczenia, iż gospodarka jest sferą doświadczeń, których jednostki w sposób konieczny zawsze są świadome" (Polanyi 1957, s. 242) ${ }^{1}$. Tym samym odrzucał przekonanie, że warunkiem koniecznym istnienia każdej gospodarki jest racjonalna kalkulacja obliczona na maksymalizację zysku, a jej aktorem jest „człowiek ekonomiczny” i jego aktywność. Przekonanie to podsyciło toczony na gruncie antropologii gospodarczej spór teoretyczny ${ }^{2}$ między formalistami i substantywistami ${ }^{3}$. Przyjętym przez siebie terminem „system rynkowy” Polanyi określa system gospodarczy, którego podstawowym mechanizmem jest rynek, na którym dokonuje się ustalanie cen (towarów i usług), skutkiem czego pieniądz staje się podstawowym środkiem wymiany. Tak rozumiany system rynkowy przeciwstawia on typom gospodarek nie posiadających rynku jako mechanizmu określającego ceny i nadającego pieniądzu rolę środka wymiany. Wymiana rynkowa zaczęła dominować w XIX wieku w kapitalizmie leseferystycznym, podporządkowującym społeczeństwo systemowi rynkowemu. Jeśli w systemach nierynkowych nie istnieje żaden odrębny system gospodarczy, który można by analizować niezależnie od społecznej organizacji, to

${ }^{1}$ W oryginale czytamy: „We must rid ourselves of the ingrained notion that the economy is a field of experience of which human beings have necessarily always been conscious" (Polanyi 1957, s. 242).

2 Więcej na temat owego sporu zob. Romaniszyn 1994.

3 Oddajmy głos Polanyiemu (1957, s. 240: "This view of the economy as the locus of units allocating, saving up, marketing surpluses, forming prices, grew out of the Western milieu of the eighteenth century and it is admittedly relevant under the institutional arrangements of a market system. [...] The claim of formal economics to an historically universal applicability answers in the affirmative. In effect this argues the virtual presence of a market system in every society, whether such a system is empirically present or not. All human economy might then be regarded as a potential supply-demand-price mechanism. [...] Approaching the economic process from the vantage point of the new knowledge we have gained the reality of society, we must say that there is no necessary relationship between economizing action and the empirical economy. The institutional structure of the economy need not compel, as with the market system, economizing action. [...] a fundamentally different starting point for the analysis of human economy as a social process is required". 
W systemie rynkowym instytucje społeczne są „anektowane” przez instytucje gospodarcze tak, że całe społeczeństwo jest „zanurzone” w ich środowisku. Jeśli systemy nierynkowe powstają i działają zgodnie ze naturą społeczną człowieka, to system rynkowy przeciwnie - przekształca go $\mathrm{w}$ homo oeconomicus. Twierdzenia te nie pozostały bez wpływu na antropologię gospodarczą, w której podsyciły wspomniany spór, nie mogły też pozostać niezauważone przez antropologów badających społeczeństwa odległe $\mathrm{w}$ przestrzeni i odmienne od ich własnego. Ze strony tych uczonych przedstawione przez Karla Polanyiego poglądy na temat systemów nierynkowych spotkały się z zarzutem idealizowania, a przez to upraszczania dużo bardziej złożonej rzeczywistości empirycznej i, co nie mniej ważne, pomijania faktu ogromnego zróżnicowania gospodarek nierynkowych (tradycyjnych). Wskazane zarzuty formułowali wytrawni badacze terenowi i antropologowie tej miary co Mary Douglas.

Według Polanyiego społeczny sprzeciw wobec dominacji w społeczeństwie zasady rynkowej może rodzić konflikt i przeciwdziałania. W nawiązaniu do tej myśli Chris Hann, pisząc o "podwójnym ruchu” (double movement) czy też ruchu i przeciw-ruchu, zauważa jej aktualność i przydatność do interpretacji współczesnych modeli wolnego handlu i reakcji na przyjęte rozwiązania. Jednak uwagę koncentruje przy tym na obszarze, którego dotyczą jego wcześniejsze badania terenowe w Polsce i na Węgrzech, a szerzej — jak sam pisze — na stronach ojczystych Karla Polanyiego. Koncepcje tego ostatniego mają pomóc w lepszym zrozumieniu przejścia od socjalizmu do rzeczywistości określanej w książce jako postsocjalizm lub — jak czytamy w innym miejscu - ich odświeżenie ma ułatwić teoretyzowanie na temat socjalizmu i jego schyłku w erze neoliberalnej globalizacji. W jednym $z$ uzasadnień wyboru tytułowego bohatera swojej książki Chris Hann stwierdza, że Karla Polanyiego można uznać za bardzo dobrego przewodnika „po” sprzecznościach zglobalizowanego kapitalizmu obecnego wieku. Można dopowiedzieć, że jest to przewodnik niekrępujący, przeciwnie - dający możliwość swobodnej (re)interpretacji swoich twierdzeń, co ułatwia pewna swoboda terminologiczna właściwa pisarstwu Polanyiego. Idąc tym tropem, Hann koncentruje się nie na systemie rynkowym, lecz na społecznym kontekście systemu, co wyraża się w stosowanym przez niego określeniu „społeczeństwo rynkowe” (market society), pisze też o kapitalizmie rynkowym (market capitalism), być może w celu podkreślenia, że wyróżnikiem kapitalizmu jest właśnie wolny rynek.

Wprawdzie $\mathrm{w}$ tytule książki jest mowa o społeczeństwie rynkowym w państwach Grupy Wyszehradzkiej, jednak autor skupia się na dwóch społeczeństwach: węgierskim i polskim. Podkreśla, że ludności zaoferowa- 
no nową wersję utopijnego myślenia w kategoriach „terapii szokowej” czy „końca historii”. Żądano też ofiary, nazywanej przejściową, na rzecz szczęśliwej przyszłości, gdy w istocie dla wielu mieszkańców środkowo-wschodniej Europy przejście do kapitalizmu rynkowego okazało się antyutopią z wielu względów, w tym dotyczących warunków i poziomu życia. Zmniejszenie wydatków publicznych oraz neoliberalna komodyfikacja pracy spowodowały - pisze Hann — wzrost napięć społecznych, a także migrację zarobkową z zamiarem sprzedaży swojej pracy na innym rynku i za wyższą cenę. Była to forma reakcji, którą można opisywać $w$ kategoriach ruchu i przeciw-ruchu. Jednocześnie masowy napływ migrantów zarobkowych zrodził w krajach przyjmujących, w tym w Wielkiej Brytanii, strach przez imigracją, co w reakcji, czyli przeciw-ruchu, stanowiło nieostatnią przyczynę Brexitu. Również podjęte w ostatnich latach działania rządów obydwu omawianych krajów na rzecz podniesienia poziomu życia obywateli, skuteczne i cieszące się uznaniem większości, ujmuje Hann w binarnym układzie „ruchu i przeciw-ruchu” - jako reakcję na neoliberalne urynkowienie (neoliberal marketization) społeczeństw, nie rezygnując przy tym z własnej krytycznej oceny tegoż przeciw-ruchu. Przyznaje wszelako, że po trzech dekadach od upadku socjalizmu oceny minionej i obecnej rzeczywistości różnicują się: doceniono uzyskaną wolność i to, że obywatele otrzymali paszporty, a wraz z nimi możliwość swobodnego poruszania się po świecie, pojawiały się nowe klasy średnie, chociaż dla niektórych aktualny pozostaje problem braku środków i dobrej pracy. Spostrzeżenia te nie zmieniają jednak jego ogólnie krytycznej oceny rzeczywistości po 1990 roku. Powołując się na Karla Polanyiego autor stwierdza, że znów jesteśmy w koszmarze liberalizmu gospodarczego (in the nightmare of economic liberalizm) i powróciła quasi-mistyczna wiara $\mathrm{w}$ rynek, a także zubożały pogląd na naturę ludzką.

Nie ulega wątpliwości, że rzeczywistość określana w książce między innymi mianem kapitalizmu rynkowego spotyka się z surową oceną Chrisa Hanna. W odwołaniu do Polanyiego stwierdza on, podkreśla i omawia fakt komodyfikacji: ziemi, pracy i pieniądza, czyli dóbr niewyprodukowanych, traktowanych jako czynniki produkcji. Jak pisze, komodyfikacja ziemi prowadzi do jej grabieży, ziemia na całym świecie jest traktowana jako najlepsza lokata kapitału, będącego pod dostatkiem. Krytyczny stosunek Chirsa Hanna do przemian zaistniałych po 1989 roku bardzo wyraźnie uwidacznia się właśnie w uwagach dotyczących kwestii własności, przede wszystkim własności ziemi. W odwołaniu do wielu antropologicznych studiów dotyczących form użytkowania i własności ziemi, w tym klasycznych ustaleń Bronisława Malinowskiego, pisze on o rolnikach w dwóch omawianych krajach jako o przegranych, którzy stracili na transformacji. 
Należy jednak zaznaczyć, że zamieszczone studia dotyczą sytuacji w latach dziewięćdziesiątych XX wieku. Autor dostrzega gruntowną poprawę sytuacji rolników i rolnictwa po przystąpieniu Polski i Węgier do Unii Europejskiej, nie jest jednak obrońcą rodzinnego gospodarstwa rolnego, pisze też o zaletach kolektywizacji. Jeśli idzie o samych zainteresowanych, to w Polsce jednoznacznie opowiedziano się za gospodarstwem rodzinnym jako podstawą ustroju rolnego w kraju, co zostało zapisane w konstytucji. Rozwiązanie to jest powszechne w krajach UE.

Karl Polanyi nie ograniczał się do tworzenia nowej teorii gospodarek ludzkich i nie zamknął się w świecie akademickich dysput dotyczących tej kwestii, przeciwnie - twórczość naukową łączył z ocenami toczących się wydarzeń. Można obrazowo powiedzieć, że jego poglądy naukowe splatały się z poglądami politycznymi, którym dawał wyraz. Zdominowanie systemu redystrybucji i systemu wymiany odwzajemnionej przez alokację rynkową uważał za istotną przyczynę wielkich kataklizmów XX wieku, czyli dwóch wojen światowych i związanych z nimi totalitaryzmów (Morawski 2011, s. 17). Niszczycielskie efekty „uwodzicielskiego rynku”, czy też samoregulacji rynkowej, dostrzegał także w atrofii więzi społecznych, zatomizowaniu społeczeństw i wzroście nędzy. Chris Hann stara się iść jego śladem i nie ogranicza swoich rozważań do kwestii akademickich, łączy je z przekonaniami i sądami natury politycznej. W tym jednak wyczerpuje się podobieństwo do mistrza. Karl Polanyi miał bowiem świadomość niebezpieczeństw dla wolności człowieka, jakie niesie ze sobą scentralizowana gospodarka, i protestował przeciw zagrożeniom cywilizacji przez „faszyzm, komunizm, wojny światowe itd.” (Morawski 2011, s. 93). Podobnie jak Mannheim szukał trzeciej drogi, sprzeciwiając się zarówno liberalnemu determinizmowi, jak i centralnemu socjalistycznemu planowaniu (Morawski 2011, s. 92). Owo centralne planowanie to podstawowa instytucja komunistycznego systemu redystrybucji, który zdominował, a w niektórych okresach i krajach wyparł pozostałe dwa sposoby alokacji dóbr. Jeśli w kapitalizmie leseferystycznym społeczeństwa podlegały systemowi rynkowemu, to w komunizmie zostały podporządkowane właśnie redystrybucji opartej na centralnym planowaniu.

Chrisa Hanna fascynuje, jak sam wspomina, zachodnia marksistowska perspektywa interpretacyjna skoncentrowana na sposobie produkcji, co może mieć wpływ na jego ocenę centralnie planowanej redystrybucji jako formy organizacji gospodarki i społeczeństwa. Z fascynacją tą spójne jest postawione we wstępie pytanie o to, czy Eurazja, czyli łącznie Europa i Azja, może przekroczyć (transcend) ideologiczne sprzeczności ery marksistowsko-leninowsko-maoistycznego socjalizmu w celu sprostania 
odpowiedzialności za przetrwanie naszej planety. Powtórzmy, rzeczywistość społeczno-gospodarcza owej ery zasadzała się właśnie na redystrybucji. Wątek ten powraca, gdy autor expressis verbis daje wyraz przekonaniu, że odpowiedzią na powstanie społeczeństwa rynkowego może być tylko powrót do redystrybucji. Długofalowym rozwiązaniem odpowiednim dla europejskiego regionu, którym się zajmował (i dla całej planety) jest utrzymuje Chris Hann - porzucenie neoliberalnych dogmatów ekonomicznych i kontynuowanie dialektyki „socjalnej Eurazji” (social Eurasia). W przedstawionej wizji przyszłość gospodarek ludzkich i trwała szczęśliwość osobista jednostek (eudajmonia) zależy od zachowania ludów Eurazji, przede wszystkim od przezwyciężenia rynkowej formy integracji za pomocą „efektywnej redystrybucji”. Historia Europy, także ta najnowsza i dotycząca krajów omawianych przez autora, skłania do dystansu wobec nowych projektów uszczęśliwiana ludzi. W przypadku redystrybucji jako formy organizacji gospodarki i społeczeństwa kluczowa jest — jak wiemy - kwestia centrum i sposobu alokacji dóbr. Niezbędne jest więc uzupełnienie przedstawionej wizji o kwestie dotyczące przyszłego centrum alokacji dóbr w Eurazji, czyli wskazanie, gdzie ono będzie, kto lub co będzie tę funkcję sprawować i w jaki sposób (za pośrednictwem jakich instytucji). Nie mniej istotna jest też sprawa dominacji redystrybucji nad dwiema pozostałymi formami organizacji gospodarki, co wymaga pełniejszego doprecyzowania przede wszystkim miejsca wymiany rynkowej i, ewentualnie, wymiany odwzajemnionej w tej Eurazji.

Pozostają jeszcze pytania o to: czy Eurazja ma wchłonąć także Unię Europejską i czy w całości? Czy ma objąć tylko te kraje Unii, które po drugiej wojnie światowej zostały włączone do bloku sowieckiego? Czy ma objąć całą Europę łącznie z Wyspami Brytyjskimi? Autor pisze, że wraz z upadkiem bloku sowieckiego i powstaniem neoliberalnej polityki gospodarczej nastapił upadek wielkiej narracji, czy zatem koncepcja „socjalnej Eurazji” jest próbą jej budowania? W nawiązaniu do tytułu książki nasuwa się też pytanie o to, czy Karl Polanyi - dziecko wolnego świata środkowej Europy opowiadające się za wolnością jednostki - chciałby się repatriować do Eurazji, urządzanej przez nową formę redystrybucji? On sam po drugiej wojnie światowej wybrał życie i pracę w społeczeństwie rynkowym.

Karl Polanyi przyczyn dwudziestowiecznych kataklizmów dopatrywał się $\mathrm{w}$ dominacji wymiany rynkowej $\mathrm{w}$ kapitalizmie leseferystycznym, ale odrzucał też komunizm ( $\mathrm{z}$ jego podporządkowaniem społeczeństw centrum alokacji dóbr) jako zagrażający prawu człowieka do wolności, w tym wolności posiadania własności prywatnej. Według Hanna zaś wierzył, że po dwudziestowiecznych katastrofach następnym etapem będzie powtór- 
ne zanurzenie gospodarki w społeczeństwie zorganizowanym według zasad demokratycznego socjalizmu, choć zdaniem innych interpretatorów szukał on trzeciej, nie socjalistycznej drogi. Zdaniem Hanna Karl Polanyi, którego nazwał socjalistą, myślał o socjalizmie rynkowym. Okazuje się, że twórczość i osoba Karla Polanyiego, za życia nazywanego też kryptomarksistą, podatna jest na wielorakie interpretacje. Jedną z nich przynosi recenzowana książka. Przedstawione w niej analizy na sposób Polanyiego (a Polanyian approach) nie przestają być analizami Chrisa Hanna.

\title{
BIBLIOGRAFIA
}

Hann Chris (red.), 1993, Socialism: Ideals, Ideologies, and Local Practice, Routledge, London.

Hann Chris, 2019, Repatriating Polanyi: Market Society in the Visegrád States, Central European University Press, Budapest.

Morawski Witold, 2011, Socjologia ekonomiczna: problemy, teoria, empiria, Wydawnictwo Naukowe PWN, Warszawa.

Polanyi Karl, 1957, The Place of Economies in Society, w: Karl Polanyi, Conrad M. Arensberg, Harry W. Pearson (red.), Trade and Market in the Early Empires: Economies in History and Theory, Free Press, Glencoe, Ill.

Romaniszyn Krystyna, 1994, Świat gospodarek ludzkich. O kształtowaniu się przedmiotu poznania antropologii gospodarczej, Uniwersytet Jagielloński, Kraków.

\section{MARKET SOCIETY AFTER SOCIALISM: CHRIS HANN'S INTERPRETATION OF POLANYI'S CONCEPTS}

\author{
Krystyna Romaniszyn \\ (Jagiellonian University)
}

\section{Abstract}

The author discusses Chris Hann's book Repatriating Polanyi, as a good opportunity for remembering Karl Polanyi's character and output. In their time, Polanyi's ideas about human economies were widely discussed in the social sciences, including in economic anthropology, and had a considerable impact on them. The text deals with those themes of Polanyi's work that Hann addresses, that is, the question of forms of economic integration and his concept of double movement.

key words: Karl Polanyi, economic anthropology, market and non-market societies, socialism, transformation, globalization, twentieth-century history and the future of Europe, Poland, Hungary, Eurasia

słowa kluczowe: Karl Polanyi, antropologia gospodarcza, społeczeństwa rynkowe i nierynkowe, socjalizm, transformacja, globalizacja, dwudziestowieczna historia i przyszłość Europy, Polska, Węgry, Eurazja 